\title{
Records of Mammals in the Lake Athabasca Area, Saskatchewan
}

\author{
by Harvey Beck, Regina
}

This report lists the records of mammals from the Lake Athabasca area of Saskatchewan. The area considered extends eastward from the Alberta-Saskatchewan border (longitude $110^{\circ}$ ) to longitude $105^{\circ}$, and southward from the District of Mackenzie-Saskatchewan border (latitude $60^{\circ}$ ) to latitude $59^{\circ}$.

The area north of Lake Athabasca is of low or moderate relief with exposed granite ridges and sparse vegetation. The northern shoreline is very irregular with long bays and small rocky islands. The area south of the lake is quite different. Sandy beaches run almost the full length of the lake and merge into dunes which alternate with patches of vegetation.

The Institute for Northern Studies, University of Saskatchewan, Saskatoon, financed collecting trips into this area in 1960 and 1961. Collections were made in the Stony Rapids-Black Lake area from July 1 to 13 and from August 11 to 24,1960 , by Mr. Wayne Davis; on the south shore of Lake Athabasca, $41 / 2$ miles east of William Point, from July 13 to 20,1961 ; and at Yakow Lake from July 24 to 28, 1961. A total of 201 specimens (47 skins with skulls, 154 skulls only) representing 14 species was collected in 1960, and 119 specimens (81 skins with skulls, 38 skulls only) representing 7 species in 1961. The specimens collected during the two summers are now part of the collection of the Biology Museum, University of Saskatchewan.
All measurements are given in millimeters in the order of total length, length of tail vertebrae, and length of hind foot. In cases where a fourth measurement is given, it is the height of ear from notch. Figures in parentheses, following average measurements and weights, represent the extremes in size of the indicated series. Weights are expressed in grams.

The following abbreviations are used in the text: INS - records made by the two surveys for the Institute for Northern Studies; SMNH - records from the Saskatchewan Museum of Natural History, Regina; USBM - records (exclusive of INS) from the Biology Museum, University of Saskatchewan; PC - personal communication (name of contributor following).

The data obtained in 1370 trap nights in July, 1961, are presented in Table 1. The data are restricted to smaller mammals normally taken with "Museum Special" traps baited with a mixture of peanut butter and rolled oats.

\section{ACCOUNTS OF SPECIES}

The sequence of family, genera, and species, and the nomenclature as well, are in general accord with Miller and Kellogg's List of North American Recent Mammals (1955).

The forms treated in the following pages that have been recorded from the Lake Athabasca area, Saskatchewan, are summarized in Table 2 .

Table 1. Trapping Data, July, 1961, south shore of Lake Athabasca

\begin{tabular}{|c|c|c|c|c|}
\hline Species & $\begin{array}{c}\text { South shore, } \\
41 / 2 \text { miles east } \\
\text { of William Pt. } \\
1020 \text { trap } \\
\text { nights }\end{array}$ & $\begin{array}{c}\text { Yakow Lake } \\
350 \text { trap } \\
\text { nights }\end{array}$ & Total & $\begin{array}{l}\text { Per Cent } \\
\text { of total } \\
\text { catch }\end{array}$ \\
\hline $\begin{array}{l}\text { Sorex cinereus } \\
\text { Eutamias minimus } \\
\text { Peromyscus maniculatus } \\
\text { Clethrionomys gapperi } \\
\text { Microtus pennsylvanicus } \\
\text { Zapus hudsonius }\end{array}$ & $\begin{array}{r}2 \\
1 \\
20 \\
21 \\
7 \\
6\end{array}$ & $\begin{array}{r}2 \\
13 \\
38 \\
4 \\
\end{array}$ & $\begin{array}{r}4 \\
1 \\
33 \\
59 \\
11 \\
6\end{array}$ & $\begin{array}{r}3.51 \\
.87 \\
28.95 \\
51.76 \\
9.65 \\
5.26\end{array}$ \\
\hline --_- & 57 & 57 & 114 & 100.00 \\
\hline
\end{tabular}




\section{Order: INSECTIVORA}

Family: SORICIDAE (Shrews)

Sorex cinereus Kerr - MASKED SHREW

Fair Point, Poplar Point, 8 miles northeast of Moose Island, mouth of Beaver River (Jackson, 1928:49); Beaverlodge Lake (SMHH); Black Lake (USBM); Stony Rapids, $4 \frac{1}{2}$ miles east of William Point, Yakow Lake (INS).

"One was found in the gizzard of a Hawk-Owl shot near Lorado on May 22, 1960." (PC: R. W. Nero).

Six specimens collected for the Institute for Northern Studies in 1960 and 1961 averaged $89.3(84-94)$ - 35.5 (3238) - 12 (12) mm; 2.5 (2-3.5) grams. A gravid female collected on the south shore of Lake Athabasca, east of William Point, carried 5 fetuses.

This species is probably more common than trapping data would indicate, but because of its small size and general inconspicuousness due to habits, little sign was noted.

Sorex arcticus Kerr - ARCTIC SHREW

Four specimens collected at Stony Rapids (INS) averaged 98.7 (84-110) $36.7(35-40)$ - $13.2(12-14) \mathrm{mm}$.

\section{Sorex vagrans Baird - WANDERING SHREW}

Four specimens collected at Stony Rapids (INS) averaged 101.2 (100-103) - 42.8 (41-45) - 13.2 (12-14) mm. (Beck, 1961:185).

Sorex palustris Richardson - WATER SHREW

Outlet of small lake near Lorado (SMNH); Stony Rapids (INS).
A single specimen was taken a Stony Rapids, 20 feet from water. It was a female and measured 138-66-19 mm.; 10 grams.

\section{Microsorex hoyi (Baird) - PYGMY} SHREW

Fond-du-Lac (USBM); Stony Rapids (INS).

The single specimen, a male, taken at Stony Rapids measured 75-25-11 mm.; 3.2 grams.

Order: CHIROPTERA

Fanily: VESPERTILIONIDAE

(Vespertilionid Bats)

Myotis lucifugus (LeConte) - LITTLE BROWN MYOTIS

Six specimens collected in August, 1945, at Crackingstone Point (USBM) averaged 91.1 (87.5-96) - 38.5 (37-41) $10(9-11)$ - tragus $8.1(8-8.5) \mathrm{mm}$.

One was collected from a colony of 20 to 30 found roosting behind a loose vertical slab of rocks on the face of a cliff about 30 feet above the ground at Bushell, Black Bay, June 16, 1960 (SMNH).

\section{[Eptesicus fuscus (Beauvois) - BIG BROWN BAT I}

The Big Brown Bat has not been recorded in the area. The nearest point of recorded occurrence is Pine Lake (24 miles south of Great Slave Lake), Alberta (Soper, 1942:125).

[Lasiurus cinereus (Beauvois) HOARY BAT!

The Hoary Bat was not detected in the area. It has been reported from Resolution on Great Slave Lake, N.W.T. (Anderson, 1947:32).

\section{Table 2. Summary of species and families found in the Lake Athabasca area.}

\begin{tabular}{|c|c|}
\hline Family & Number of Species \\
\hline oricidae（Shrews） & \\
\hline Vespertilionidae (Vespertilionid Bats) & 1 (2 others probably occur) \\
\hline Leporidae (Rabbits and Hares) & \\
\hline Sciuridae (Squirrels and Relatives) & 3 (1 other probably occurs) \\
\hline $\begin{array}{l}\text { Castoridae (Beavers) - } \\
\text { Cricetidae (Cricetids) }\end{array}$ & 1 (1 ather noccibly occurs) \\
\hline $\begin{array}{l}\text { Cricetidae (Cricetids) } \\
\text { Muridae (Murids) }\end{array}$ & $\begin{array}{l}6 \text { (1 other possibly occurs) } \\
1\end{array}$ \\
\hline Zapodidae (Jumping Mice). & 1 \\
\hline Erethizontidae (New World Porcupines) & 1 \\
\hline Canidae (Wolves, Coyotes, Dogs and Foxes) & 4 \\
\hline Mustelidae (Mustelids) & \\
\hline Felidae (Cats and Allies) & 1 (1 other probably occurs) \\
\hline Cervidae (Cervids) & 3 \\
\hline
\end{tabular}




\section{Order: LAGOMORPHA}

Family: LEPORIDAE (Rabbits and Hares)

Lepus americanus Erxleben - SNOWSHOE RABBIT

Mouth of Charlot River, Island in Tsalwor Lake (Harper, 1932:29); Stony Rapids, Woodcock Falls (INS).

The average measurements of the four Institute for Northern Studies specimens are: $393.2(320-455)-29.7$ $(27-40)-62.7(53-73) \mathrm{mm}$.

Mr. T. Heaslip, formerly of Lorado, reports "flushing" a Snowshoe Rabbit in the Lorado area on October 15, 1957, that had its upper parts still gray-brown while the underparts and legs were white.

On May 17, 1960, "some snowshoes still show white; one a few days ago was full gray, but not pure white. Abundant in Lorado vicinity in summer of 1960." (PC: R. W. Nero).

Several specimens and numerous tracks were seen on the south shore of Lake Athabasca between William and Beaver Points, and tracks were noted around Yakow Lake, in July, 1961.

\section{Order: RODENTIA}

Family: SCIURIDAE (Squirrels and Relatives)

[Marmota monax (Linnaeus) - WOODCHUCK]

The Woodchuck has not been recorded in the area. It has been reported from Wood Buffalo Park (Soper, 1942:133).

\section{Eutamias minimus (Bachman) - LEAST} CHIPMUNK

Poplar Point, mouth of MacFarlane River (Howell, 1929:57); Stony Rapids, Black Lake, $4 \frac{1}{2}$ miles east of William Point (INS).

Three specimens from Stony Rapids and one from Black Lake averaged $201.5(197-210)$ - $82.7(74-90)-32(31-$ 33) - 15.7 (15-16) mm.; 47.5 (41-51) grams.

J. B. Tyrrell (1896:14D) found chipmunks in wooded country southeast of Lake Athabasca in the summer of 1892.

A portion of skull with hide attached was found in Jack Pine forest on the edge of William River, 6 miles from mouth, on July 25, 1960 (SMNH).

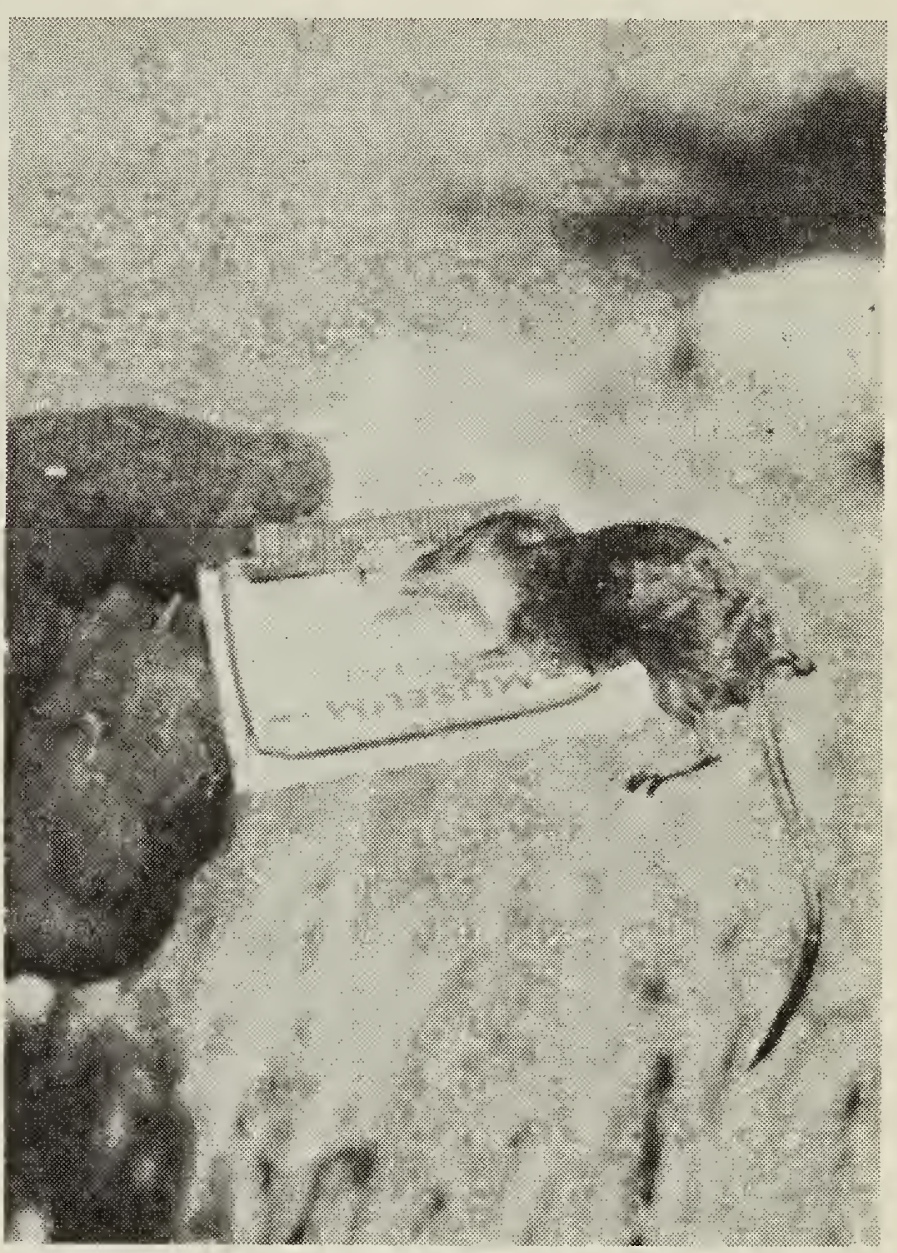

Photo by F. W. Lahrman. Water Shrew, near Uranium City (Lorado), July 14, 1960.

Tamiasciurus hudsonicus (Erxleben) RED SQUIRREL

Mouth of Charlot River, Tazin River below Tazin Lake (Harper, 1932:27); Fond-du-Lac (USBM); Lorado, 5 miles west of Beaver Point (SMNH); Black Lake (INS, USBM); Stony Rapids, William River - 6 miles upstream (INS).

Seventeen specimens from Stony Rapids averaged 323.9 (294-343) - 123.6 $(115-130)-50.4$ (48.53) - $24.6(21-28)$ inm.; 217.4 (175-263) grams.

When he explored the area between Churchill River and the eastern end of Lake Athabasca in 1892, J. B. Tyrrell (1896:14D) found Red Squirrels everywhere in the wooded country southeast of Lake Athabasca.

Several Red Squirrels were seen at Yakow Lake in July, 1961.

Glaucomys sabrinus (Shaw) -

NORTHERN FLYING SQUIRREL

Two specimens collected at Stony Rapids (INS) measured as follows: female, 290-134-42-21 mm., 118 grams; and male, 229-128-43-22 mm., 129 grams.

Mr. T. Heaslip noted a flying squirrel gliding down a snow bank near Lorado at 2:00 a.m. on March 20, 1960. 
One was reported seen by Heaslip several times near Lorado mill, on garbage cans, in June, 1960 (PC: R. W. Nero).

\section{Family: CASTORIDAE (Beavers)}

Castor canadensis Kuhl - BEAVER

Preble (1908:194) reported that in 1903 a "considerable number" of skins were traded at Fond-du-Lac.

On May 7, 1959, T. Heaslip reported beaver seen sitting on an ice floe on a small lake in the vicinity of Lorado.

"Beaver lodges were noted on two lakes in Lorado vicinity in summer of 1960. Indians were trapping them in May and in the second or third week I saw fresh tail and hind feet left by them at their overnight camp." (PC: R. W. Nero).

Beaver sign was seen on the south shore of Lake Athbasca in July, 1961.

\section{Family: CRICETIDAE (Cricetids)}

Peromyscus maniculatus (Wagner) -

DEER MOUSE

Mouth of Charlot River (Harper, 1932:28); Fond-du-Lac, Crackingstone Point (USBM); Lorado, 5 miles west of Beaver Point (SMNH); Black Lake (INS, USBM); Stony Rapids, Woodcock Falls, 41/2 miles east of William Point, Yakow Lake (INS).

Forty adults collected for the Institute for Northern Studies averaged 147.6 (122-173) - 60.4 (49-75) - 20.3 (1822) - 17.4 (15-20) mm.; 17.2 (11-28) grams. A gravid female collected July 16,1961 , on the south shore of Lake Athabasca, carried 6 fetuses.

Approximately $29 \%$ of the small mammals trapped in 1961 were of this species. It was the second most abundant species taken, being exceeded in number only by Clethrionomys.

Three species of flea were found on specimens collected in July, 1961, 41/2 miles east of William Point: Monopsyllus wagneri systaltus (Jordan), Orchopeas leucopus (Baker), and Epitedia wenmanni (Rothschild).

Synaptomys borealis (Richardson) -

NORTHERN BOG LEMMING

One was collected in heavy sedge in a bog near Lorado, July 2, 1960, and the skull was collected from one found dead on July 13, 1960, on a road through the bog (SMNH).

\section{Clethrionomys gapperi (Vigors) -}

GAPPER'S RED-BACKED MOUSE

Camsell Portage (USBM); Lorado (SMNH); Black Lake (INS, USBM); Stony Rapids, .Woodcock Falls, Uranium City, $41 / 2$ miles miles east of William Point, Yakow Lake (INS).

Sixty-seven adults collected for the Institute for Northern Studies averaged 136.9 (124-153) - $32.6(25-40.5)$ $19.4(18-21)$ - $14.6(12-17)$ mm.; 26.3 (18-40) grams.

One female carried 7 fetuses, eight carried 6 , seven carried 5 , one carried 4 , and one carried 3.

Gapper's Red-backed Mouse was the commonest cricetid found in the locations visited in July, 1961, comprising slightly over $50 \%$ of the trapping catch. Specimens were collected in all types of habitat, from Jack Pine stands on sand to sphagnum bogs.

Fleas, Peromyscopsylla selenis (Rothschild) and Megabothris quirini (Rothschild), were collected from specimens $41 / 2$ miles east of William Point; Peromyscopsylla selenis (Rothschild) and Orchopeas leucopus (Baker) from specimens at Yakow Lake in July, 1961. Dermanyssid mites were found on specimens taken in both these localities.

\section{Phenacomys ungava Merriam -} HEATHER VOLE

Crackingstone Point (Howell, 1926: 29); Lake Athabasca (Anderson, 1947: 151).

\section{Microtus pennsyllanicus (Ord) -} MEADOW VOLE

Fond-du-Lac (USBM); L o r a d o (SMNH); Stony Rapids, Black Lake, $41 / 2$ miles east of William Point, Yakow Lake (INS).

Thirty-four adults collected for the Institute for Northern Studies averaged 144.3 (122-179) - 34.7 (25-50) 20.3 (19-29) mm.; 32.5 (18-60) grams. The average height of ear from notch for 19 adults was 12.9 (11-15) $\mathrm{mm}$.

Three females each carried 8 fetuses, one carried 7 , one carried 6 , three carried 5 , and one carried 4 .

The 11 specimens taken in 1961 were all found in moist, grassy areas.

[Microtus xanthognathus (Leach) YELLOW-CHEEKED VOLE]

This vole has not been reported in Saskatchewan. It was reported at Fort 
Smith, N.W.T. (Hall and Cockrum, 1953:434).

\section{Ondatra zibethicus (Linnaeus) - MUSKRAT}

A single specimen collected at Stony Rapids for the Institute for Northern Studies measured 483-180-75-20 mm.

J. B. Tyrrell (1896:13D) reports seeing muskrat swimming in all the streams southeast of Lake Athabasca during his explorations in the summer of 1892 .

In the second week of May, 1960, one was seen in a small pool south of Lorado (PC: R. W. Nero).

A few muskrat were seen between Stony Rapids and Black Lake in the summer of 1960 , but there appeared to be no great population of them (PC: W. Davis).

Family: MURIDAE

Mus musculus Linnaeus - HOUSE MOUSE

A flattened specimen, unquestionably this species, was found in an alley in Uranium City on June 29, 1960." (PC: R. W. Nero).

Family: ZAPODIDAE (Jumping Mice) Zapus hudsonius (Zimmerman) -

MEADOW JUMPING MOUSE

Near Beaver Point (SMNH); Stony Rapids, Black Lake, $41 / 2$ miles east of William Point (INS).

Twenty-one specimens collected for the Institute for Northern Studies averaged 201.8 (192-213) - 120.9 (112130) $30.8(29-32)-13.5$ (12-15) mm.; $14.8(10-22)$ grams. Two gravid females carried 3 and 6 fetuses respectively.

The specimens collected $41 / 2$ miles east of William Point in July, 1961, were found in willows and grass at the edge of the lake.

\section{Family: ERETHIZONTIDAE (New} World Porcupines)

Erethizon dorsatum (Linnaeus) PORCUPINE

One seen near Lorado, June 6, 1960. About 36 Porcupine hairs were found in the lining of an active nest of a Swainson's Thrush (Hylocichla ustulata) near Lorado on June 28, 1960." (PC: R. W. Nero).

Tracks were observed in the vicinity of Yakow Lake in July, 1961.
Order: CARNIVORA

Family: CANIDAE (Wolves, Coyotes, Dogs, and Foxes)

Canis latrans (Say) - COYOTE

T. Heaslip reported a coyote howling during the night of April 10, 1960, near Lorado. There was a full moon at the time.

Tracks, which appeared to be of coyote, were seen in the sand of the south shore of Lake Athabasca, west of William Point, in July, 1961.

Canis lupus, Linnaeus - GRAY WOLF

Carcasses were noted at the mouth of the Charlot River (Harper, 1932:26). Tracks were seen at Thainka Lake (ibid), 5 miles west of Beaver Point (Nero, 1961:63), and, in July, 1961, 41/2 miles east of William Point.

T. Heaslip noted one running along a road near Lorado at 2:00 a.m., March 3, 1960.

Alopex lagopus (Linnaeus) - ARCTIC FOX

Mr. Pat Kerr of Gunnar reported on February 4, 1962, that "during the fall and so far this winter the trappers around Gunnar have caught several Arctic Fox."

Vulpes vulpes Linnaeus - RED FOX

Stony Rapids, Harper Lake (PC: C. S. Churcher); 8 miles southwest of Beaver Point (Nero, 1961:66).

Signs indicated predation on the Arctic Tern (Sterna paradisaea) at their nesting ground on the south shore of Lake Athabasca (Nero, 1961: 66).

Tracks were seen $4 \frac{1}{2}$ miles east of William Point and near Yakow Lake, in July, 1961.

Family: URSIDAE (Bears)

Euarctos americanus Pallas - BLACK BEAR

J. W. Tyrrell (1897:73) reported that in July, 1893, 7 miles upstream from Wolverine (=Chipman) Lake, "I suddenly came within full view of an immense black bear seated on his haunches and occupied in rubbing the mosquitoes off his nose."

One was seen near Stony Rapids garbage dump, and fresh droppings and tracks were seen near Woodcock Falls; in July, 1960 (PC: W. Davis).

Sign was noticed 5 miles west of Beaver Point in 1960 (Nero, 1961:63) and was common $4 \frac{1}{2}$ miles east of 


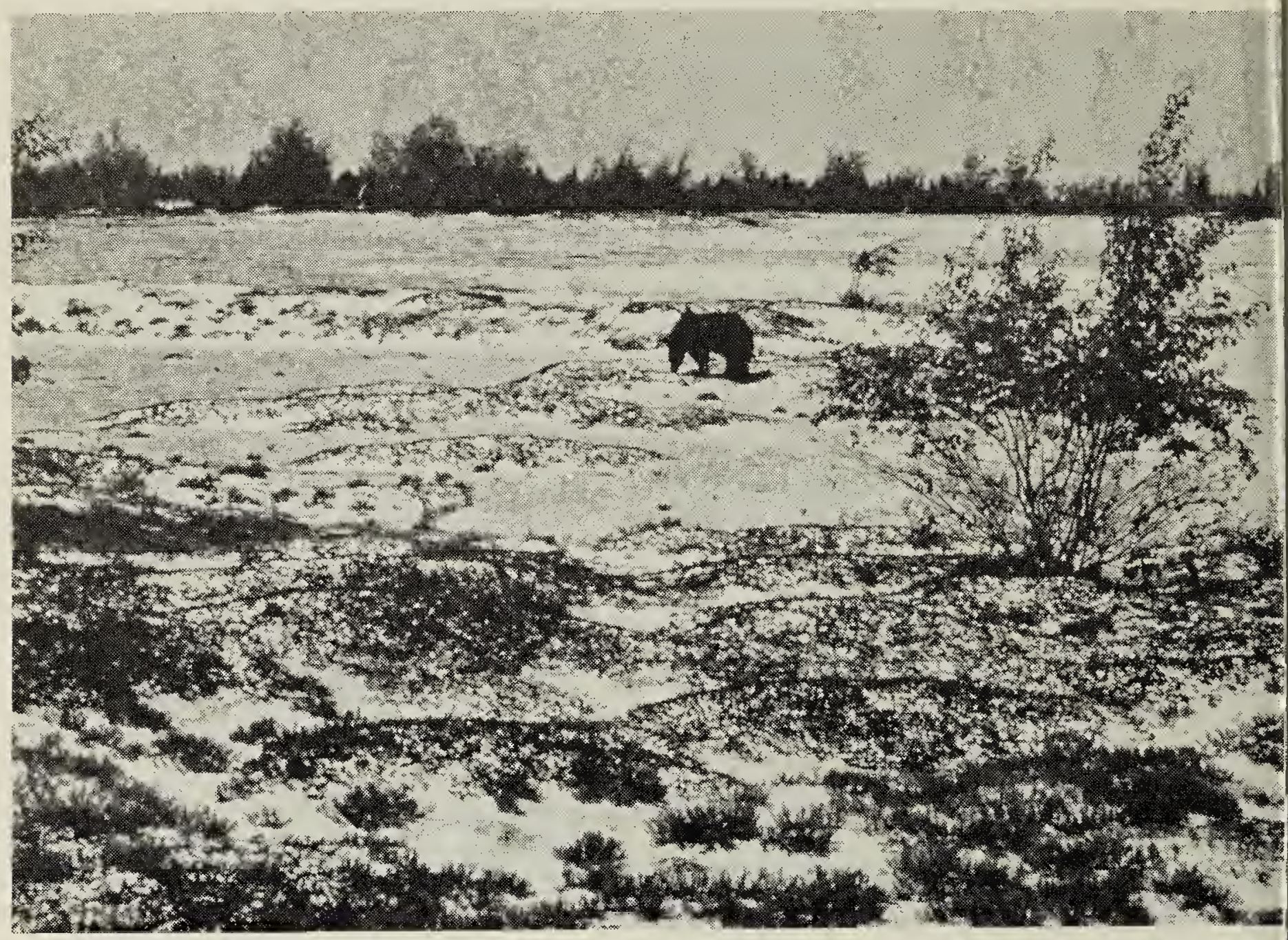

Photo by G. W. Argus

Black Bear in the sand dunes near Yakow Lake, south shore of Lake Athabasca, July 21, 1962.

William River in July, 1961. Tracks were present in the sand around Yakow Lake, and a black bear was seen in a sphagnum bog near Yakow Lake on July 27, 1961.

Family: MUSTELIDAE (Mustelids)

Martes americana (Turton) - MARTEN

Chipman Lake (Scotter, 1961:133).

Tracks were observed near Yakow Lake, July 25, 1961.

Martes pennanti (Erxleben) - FISHER Crackingstone Creek (SMNH).

Mustela erminea, Linnaeus ERMINE

Poplar Point, Fair Point, Harper Lake (Hall, 1951:118).

On August 21, 1959, T. Heaslip saw one hunting mice at an old warehouse, Lorado.

"Indians at Stony Rapids reported that ermine are quite plentiful in the area and are ofen caught in the winter." (PC: W. Davis).

\section{Mustela rixosa (Bangs) - LEAST WEASEL}

Beach at Beaverlake Lodge, Eldo- rado townsite on July 13, 1960 jaw fragment (SMNH).

"Small weasel tracks identified as this species in dunes (south shore Lake Athabasca) on July 22, 1960." (PC: R. W. Nero).

Mustela vison, Schreber - MINK

Tazin River 10 miles below Thainka Lake (Harper, 1932:23).

"Residents of Stony Rapids report them near the town." (PC: W. Davis). Gulo luscus (Linnaeus) - WOLVERINE

Near Fond-du-Lac (Seton, 1911:253).

Tracks were seen near Yakow Lake on July 25, 1961.

Mephitis mephitis (Schreber) STRIPED SKUNK

"Tracks were'seen 5 miles west of Beaver Point, July 9, 1960. Tracks of several were seen in the dunes on July 22,1960 . One was 'flushed' by a dog on August 7, 1960, edge of beach, south shore of Lake Athabasca, west of Beaver Point." (PC: R. W. Nero).

Tracks were noted in the dunes $41 / 2$ miles east of William Point in July, 1961. 


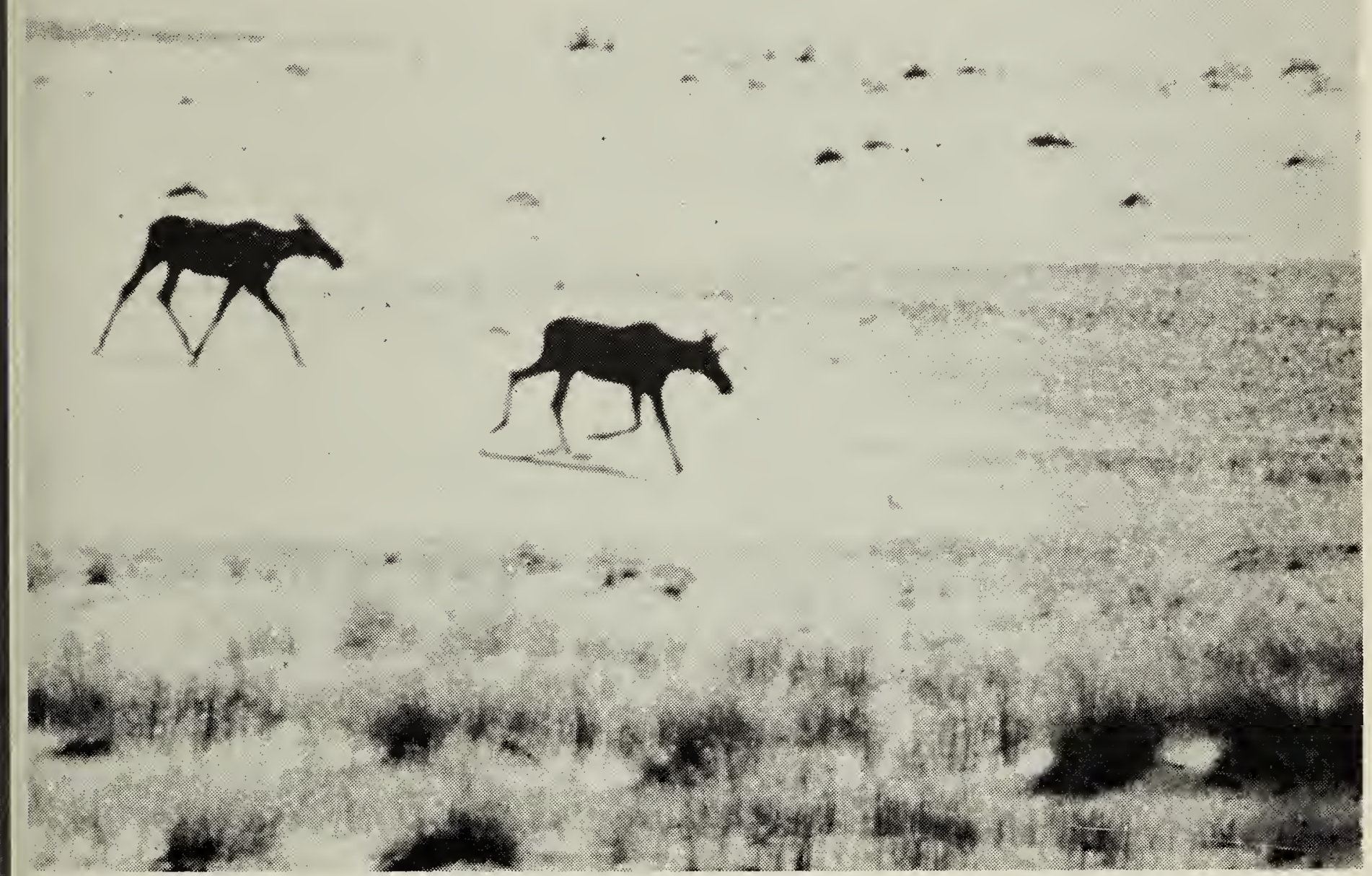

Photo by F. W. Lahrman Moose crossing the sand dunes near Beaver Point, Lake Athabasca, July, 1960.

Lutra canadensis (Schreber) - RIVER OTTER

J. B. Tyrrell (1897:166F) reports that otter "live on the banks of the streams throughout the country" southeast of Lake Athabasca.

Tracks were seen in the sand near water on the south shore of Lake Athabasca, east of William Point, in July, 1961.

Family: FELIDAE (Cats and Allies) Felis concolor Kerr - MOUNTAIN LION

An employee at Eldorado, on June 21 , 1960, reported that a strange animal had been seen two weeks previously at Eldorado. The description was that of a Mountain Lion. The previous year a similar animal had been seen near Lorado (PC: R. W. Nero).

Lynx canadensis Kerr - LYNX

Tsalwor Lake (Harper, 1932:26).

On July 20, 1959, T. Heaslip saw a lynx pursuing a rabbit along a road at Lorado at 2:00 a.m. "One was seen near Lorado on edge of road about third week of July, 1960." (PC: R. W. Nero).

Tracks were seen in the sand dunes $41 / 2$ miles east of William Point, and in the vicinity of Yakow Lake, in July, 1961.

Order: ARTIODACTYLA

Family: CERVIDAE (Cervids)

Odocoileus hemionus (Rafinesque) MULE DEER

Deer tracks were identified in the dunes west of Beaver Point on July 25, 1960 (PC: R. W. Nero), and $41 / 2$ miles east of William Point in July, 1961. Although no deer were seen, this is probably the species that occurs.

Alces alces (Linnaeus) - MOOSE

While exploring the country between Lake Athabasca and the Churchill River in the summer of 1892, J. B. Tyrrell (1896:13D) found that the moose "roams through the more thickly wooded parts of the country as far north as Stone (=Fond-du-Lac) River."

Harper Lake (Peterson, 1952:27). Sign was noted at Tazin and Thainka 
Lakes (Harper, 1932:30), 5 miles west of Beaver Point (Nero, 1961:63), in Lorado vicinity in summer, 1960 (PC: R. W. Nero), and at Yakow Lake in July, 1961. At least one moose was killed at Middle Lake in August, 1960 (PC: W. Davis). A bull, cow, and calf were seen $41 / 2$ miles east of William Point on July 15, 1961.

\section{Rangifer arcticus (Richardson) - \\ BARREN GROUND CARIBOU}

Banfield (1954:16) reported Barren Ground Caribou from the "northern shore of Lake Athabasca southward . . " J. B. Tyrrell (1896:63D) stated that in 1892 Fond-du-Lac was "on one of the principal lines of travel of the Barren Ground Cariboo, in their regular migrations north and south." Residents of Uranium City report seeing them in varying numbers every year. Occasionally caribou wander through the town, but they are more common east, toward Pine Channel.

"On April 28, (1957), more than 14,000 caribou crossed Lake Athabasca between Stony Rapids and Camsell Portage. This mass movement had a depth of nearly 100 miles and extended toward the northeast on a front 150 miles wide." (Kelsall, 1960:7).

An antler was seen at Thainka Lake (Harper, 1932:30), and antlers were noted $41 / 2$ miles east of William Point and at Yakow Lake in July, 1961.

T. Heaslip made the following records of caribou:

April 27, 1957. Caribou seen crossing Nero Lake in late evening.

April 30, 1957. Many caribou crossing Nero Lake at sunset.

May 1, 1957. Caribou crossing Martin Lake.

April 27, 1960. Seven caribou seen crossing Beaverlodge Lake.

Fresh tracks of one were seen in the second week of May, 1960, at Lorado (PC: R. W. Nero).

\section{LITERATURE CITED}

Anderson, R. M. 1947. Catalogue of Canadian recent mammals. Bull. Nat. Mus. Can., 102: $v+238$.

Banfield, A. W. F. 1954. Preliminary investigation of the barren-ground caribou. Pt. 1: Former and present distributions, migrations, and status. Canadian Wildlife Serv., Wildlife Mgt. Bull., ser. 1, 10A:1-79.

Beck, W. H. 1961. Range extension of the wandering shrew. The Blue Jay, 19:185.
Hall, E. R. 1951. American weasels. Univ Kansas Pub., Mus. Nat. Hist., 4:1-466.

Hall, E. R., and E. L. Cockrum. 1953. synopsis of North American microtin rodents. Univ. Kansas Publ., Mus. Nat Hist., 5:373-498.

Harper, F. 1932. Mammals of the Athabaska and Great Lakes region. Jour. Mamm., 13: 19-36.

Howell, A. B. 1926. Voles of the genus Phenacomys. N. Amer. Fauna, 48: iv +66.

Howell, A. H. 1929. Revision of the American chipmunks (genera Tamias and Eutamias). N. Amer. Fauna, 52:1-157.

Jackson, H. H. T. 1928, A taxonomic review of the American long-tailed shrews (genero Sorex and Microsorex). N. Amer. Fauna, 51: vi +238 .

Kelsall, J. P. 1960. Co-operative studes of barren ground caribou, 1957-58. Canadian Wildlife Ser., Wildlife Mgt. Bull., ser. 1, 15: 1-145.

Miller, G. S., and R. Kellogg. 1955. List of North American recent mammals. Bull. U.S. Nat. Mus. 205xii + 954 .

Nero, R. W. 1961. The Arctic Tern in Saskatchewan. The Blue Jay, 19:60-67.

Peterson, R. L. 1952. Review of living representatives of the genus Alces. Contrib. Royal Ontario Mus. Zool. and Palaeo., 34: 130.

Preble, E. A. 1908. A biological investigation of the Athabaska-Mackenzie region. $N$. Amer. Fauna, 27:1-574.

Scotter, G. W. 1961. Notes on behaviour of marten in Saskatchewan. The Blue Jay, 19:133.

Seton, E. T. 1911. The Arctic Prairies. New York.

Soper, J. D. 1942. Mammals of Wood Buffalo Park, northern Alberta and District of Mackenzie. Jour. Mamm., 23:119-145.

Tyrrell, J. B. 1896. Report on country between Athabasca Lake and Churchill River with notes on two routes travelled between the Churchill and Saskatchewan Rivers. Ann. Rept., Can. Geol. Survey, viii (new series), 1895, 5D-120D.

Tyrrell. J. B. 1897. Report on the Doobaunt, Kazan and Ferguson Rivers and the northwest coast of Hudson Bay, and on two overland routes from Hudson Bay to Lake Winnipeg. Ann. Rept. Can. Geol. Survey, ix (new series), 1896, F.

Tyrrell, J. W. 1897. Across the Sub-Arctics of Canada. William Briggs, Toronto.

\section{A GUIDE TO SASKATCHEWAN} MAMMALS

\section{by W. H. Beck}

Still available in the series of SNHS special Publications is the bulletin that launched the series, Harvey Beck's Guide to Saskatchewan Mammals, price 50 cents. This 52-page guide, with maps, sketches and photographs, was published in 1958. Order from Frank Brazier, Box 1121, Regina.

Consider one or more of the Society's Special Publications as Christmas gifts. An order sent to the Treasurer will get a prompt reply. 